\title{
Threats to Sustainable Livestock Production in Sudan
}

\author{
Abu Bakr El Siddig Ahmed El Tohami* \\ Associate Professor of Environmental management and fac Impact Assessment, Omdurman Ahlia University, Sudan \\ Received: 啙: September 22, 2018; Published: 些 October 01, 2018 \\ *Corresponding author: Abu Bakr El Siddig Ahmed El Tohami, Associate Professor of Environmental management and fac Impact \\ Assessment, Omdurman Ahlia University, Sudan
}

\begin{abstract}
Sudan is famous for livestock production all over the world. Nevertheless, livestock production was faced by a lot of obstacles. This paper focuses on identifying these barriers. Holistic overview of the past, present and future challenges of sustainable livestock production was used to identify these constraints. They can be summed up into natural and man -made factors which are interacting together to hinder sustainable management of both animals as well as range resources of the country. Natural factors can be summarized as follows: most of range resources of the range resources of Sudan in semi-arid and sensitive fragile areas, alternating dry and wet periods, desertification, climate changes, pests and diseases, soil types and geomorphological factors. While man made factors can be grouped into: local culture, conflicts between herders and cultivators, seasonal bush fires, dissolution of native administration, nomadic tribes coming from neighbouring countries, poor range management, grazing systems adopted, etc.

From the other hand, the above mentioned constraints have resulted in negative socioeconomic impacts such as loss of herds, migration of herders to the outskirts of the neighbouring urban centres, socio-cultural changes, family disintegration and lack of essential livelihood services, etc. Sustainable livestock production can be attained through changes in the prevailing local cultures that the number of animals is the source of political power and social prestige, adoption of sustainable practices that help in reducing overgrazing and range deterioration, rehabilitation of fire lines and strengthening the role of local institutions for adopting indigenous cultural practices, etc.
\end{abstract}

\section{Introduction}

The area devoted for range and forestry in Sudan is about $61.3 \%$ of the total area of the country. The total range lands is about 187 million feddans (a feddan is equivalent to 0.42 Hectare) Natural rangers are contributed with about 87 million tons while the irrigated forages are providing 4 million tons, 22 million tons from agro-industries' by products, totaling 105 million tons per year from the previously mentioned sources [1,2].

The pastoralism in Sudan is of three types: Pastoral nomadism where the herders are in continuous movement with their looking after forage and water in the dry months of the year and/or to avoid mud and mosquitoes during the rainy season. The second type is the seminomadic where the cultivation while the rest of the family moves with the herds looking for forages and water. The Third type is the Sedentary pastoralism where the major economic activity is agriculture. Their herds graze in the vicinity of the villages $[3,4]$.

\section{Objective}

This article aims at identifying the threats to sustainable livestock production in Sudan.

\section{Method}

It is a review article therefore a critical review of the available literature has been carried out to satisfy the above-mentioned objectives.

\section{Causes of Unsustainable Livestock Production}

The causes can be presented as follows:

a) Continuous increase in animals' number which resulted from the fact the nomads are in continuous movement, poor marketing channels, local culture regarding animals' number, improving of the veterinary services, etc.

b) Land degradation through overuse or misuse, population growth or displacement, disadvantageous change in land tenure, cause lasting damage the people, animals and environment [2].

c) Insecurity of land ownership. The government of Sudan owns all land in the country, but it does not practice any control over its use [2].

d) The horizontal expansion of the rain fed mechanized schemes over vast areas of range lands and natural forests had resulted in squeezing of the herders out of their traditional grazing sites. The impact of this expansion could be summarized as follows: disappearing of the livelihoods for dry lands and pastoral societies, abandoning pastoralism in favour of sedentary agriculture, or displacement to cities, more permanent annual herd movement southwards where there is abundant water and forage, change in herd composition replacing large animals by small animals like goats, maximizing 
herd's size as an insurance measures against drought and mortality, competition over range resources which has resulted in conflicts between herders even from the same tribe, blocking of the traditional animals' migratory routes or routes leading to the water points led to conflicts between farmers and herders.

e) Deforestation and decrease of perennial grasses due overgrazing and spread of annual and exotic plant species.

f) Fire and fire line maintenance: Annually fires destroy $47 \%$ of the total range land in the country due to the absence of regular maintenance of fire lines after the dissolution of native institutions in 1970.

g) Dissolution of native administration which were responsible for solving conflicts between herders and cultivators as well as maintenance of fire lines.

h) Micro and macroclimatic changes which are contributing to poverty and conflict.

i) Oil exploration and its impacts on herders and their herders.

j) Most oil exploration areas in Sudan y confined to the majority of range lands in South and West Kordofan States which are more than $80 \%$ of the total area of these two states.

k) Traditional animal migratory routes had been blocked by the construction of new roads.

l) Range lands had been polluted by the petroleum wastes which are hazardous to the grazing animals.

m) Cattle in Eastern Sudan were prohibited from grazing nearer to Bashyer oil exporting port [3].

n) Periodic maintenance of the traditional migratory routes are difficult because of oil exploration activities [4].

o) Local inhabitants of Abu Jabara fields are complaining from the contamination of their drinking water resources from the wastewater resulted from oil exploration and drilling [4].

p) Impacts of Unsustainable livestock production: Nomadism in Sudan in its way to disappear in Eastern and Central Sudan [4].

ISSN: 2574-1241

DOI: 10.26717/BJSTR.2018.09.001809

Abu Bakr El Siddig Ahmed El T. Biomed J Sci \& Tech Res

(c) (i) This work is licensed under Creative Commons Attribution 4.0 License

Submission Link: https://biomedres.us/submit-manuscript.php q) Large animals are replaced by small ruminants such as goats at the expense of cattle [4].

r) Drought has resulted in loss of herds and therefore enforcing herders to move to the outskirts of cities living in slums without the essential community services such as potable water and waste management and schools and health services [3].

s) Some nomads nowadays are working as casual labour in mechanized agricultural scheme after the loss of their herds [4].

\section{Conclusion}

Livestock Production is seemed to be non- sustainable due to anthropogenic (man-made) and natural factors.

\section{Recommendations}

Sustainable livestock production can be attained through:

a) Change in the attitude and local culture that consider the number of animals is a source of political power and social prestige [5].

b) Regular maintenance and rehabilitation of fire line [6].

c) Traditional migratory routes should be registered and to be maintained opened all year around [7].

d) Adoption of Indigenous cultural practices [4,5].

e) Strengthening the role of local institutions.

\section{References}

1. Abu Suwar OA (2007) Range Management, Uniseco Chair of Desertification, University of Khartoum, Khartoum University Printing Press, Sudan.

2. UNEP (2007) Sudan Post Conflict: Environmental Assessment, Nairobi.

3. De Jong CB (1991) Environmental Problems of the Sudan, Haigue, The Netherlands.

4. El Tohami AEA (2013) Indigenous Cultural Practices: A path for Green Production.

5. El Tohami AEA (2013) Threats to food security in Sudan.

6. El Tohami AEA (2018) Smart agriculture from a Sudanese perspective.

7. Personal experience of the author (2018). 